\title{
Salinity of the southern part of the state of the Baltic Sea (area Międzyzdroje)
}

\author{
Piotr Daniszewski \\ Department of Invertebrate Zoology and Limnology, Faculty of Biology, University of Szczecin, \\ 13 Wąska Street, 71-415 Szczecin, Poland \\ E-mail address: daniszewski73@gmail.com
}

\begin{abstract}
This paper presents a study on the salinity of the Baltic Sea in Międzyzdroje. The study was conducted from February 2008 to September 2009 year. The highest concentration of $[\mathrm{NaCl}]$ in said month May 2009 was about $4.51 \mathrm{~g} / \mathrm{dm}^{3}$, while the lowest occurred in the month February 2009 was about $3.45 \mathrm{~g} / \mathrm{dm}^{3}$.
\end{abstract}

Keywords: salinity waters; Baltic Sea; Międzyzdroje

\section{INTRODUCTION}

Urbanization is the cause of many changes which are taking place in the environment, including those found in the catchment. With this in mind, it is an important issue to properly protect water reservoirs and also take action to counter the adverse effects of human activities on the natural environment, including water bodies [1-5,7-19].

The salinity of the Baltic Sea during the last twenty years, steadily declining. Scandinavian mantle uplift makes the Danish Straits are getting shallower. The result of this uplift is slow, but systematic reduction of the power of the Baltic Sea by the North Sea with a much higher salt content.

\section{EXPERIMENTAL}

The Baltic Sea is a mediterranean sea located between Central and Northern Europe, from $53^{\circ} \mathrm{N}$ to $66^{\circ} \mathrm{N}$ latitude and from $10^{\circ} \mathrm{E}$ to $30^{\circ} \mathrm{E}$ longitude. It is bounded by the Scandinavian Peninsula, the mainland of Europe, and the Danish islands [20-24]. It drains into the Kattegat by way of the Øresund, the Great Belt and the Little Belt. The Kattegat continues through Skagerrak into the North Sea and the Atlantic Ocean. The Baltic Sea is connected by artificial waterways to the White Sea via the White Sea Canal, and to the North Sea via the Kiel Canal [20-24]. The Baltic Sea might be considered to be bordered on its northern edge by the Gulf of Bothnia, on its northeastern edge by the Gulf of Finland, and on its eastern edge by the Gulf of Riga. These various gulfs can also be considered part of the Baltic Sea [20-24]. Results of the determination of anions in sea water were taken for chloride by Mohr's method [25]. 


\section{RESULTS AND DISCUSSION}

In the calculation of salinity in the vicinity of the southern Baltic Międzyzdoje proposed methodology was used by Pazdro and Kozerski (1990), in one mole of $\mathrm{NaCl}$ is:

$23 \mathrm{~g}\left[\mathrm{Na}^{+}\right]+35 \mathrm{~g}\left(\mathrm{Cl}^{-}\right)=58 \mathrm{~g}[\mathrm{NaCl}]$.

If in seawater from the Baltic Sea in February 2008 sodium ion content was $1.42 \mathrm{~g} / \mathrm{dm}^{3}$ $\left[\mathrm{Na}^{+}\right]$, is the ratio of:

$23 \mathrm{~g}\left[\mathrm{Na}^{+}\right]-58 \mathrm{~g}[\mathrm{NaCl}]$

$1.42 \mathrm{~g}\left[\mathrm{Na}^{+}\right]-\mathrm{X}$

$\mathrm{x}=3.58 \mathrm{~g} / \mathrm{dm}^{3}[\mathrm{NaCl}]$.

The remaining amount of chloride ions derived from the other compounds.

If in seawater from the Baltic in May 2008 contents sodium ion was $1.71 \mathrm{~g} / \mathrm{dm}^{3}\left[\mathrm{Na}^{+}\right]$is the ratio of:

$23 \mathrm{~g}\left[\mathrm{Na}^{+}\right]-58 \mathrm{~g}[\mathrm{NaCl}]$

$1.71 \mathrm{~g}\left[\mathrm{Na}^{+}\right]-\mathrm{X}$

$\mathrm{x}=4.31 \mathrm{~g} / \mathrm{dm}^{3}[\mathrm{NaCl}]$

The remaining amount of chloride ions derived from the other compounds.

If in seawater from the Baltic in September 2008 ion content was $1.65 \mathrm{~g} / \mathrm{dm}^{3}$ sodium $\left[\mathrm{Na}^{+}\right]$is the ratio of:

$23 \mathrm{~g}\left[\mathrm{Na}^{+}\right]-58 \mathrm{~g}[\mathrm{NaCl}]$

$1.65 \mathrm{~g}\left[\mathrm{Na}^{+}\right]-\mathrm{x}$

$\mathrm{x}=4.16 \mathrm{~g} / \mathrm{dm}^{3}[\mathrm{NaCl}]$.

The remaining amount of chloride ions derived from the other compounds.

If in seawater from the Baltic Sea in February 2009 sodium ion content was $1.37 \mathrm{~g} / \mathrm{dm}^{3}\left[\mathrm{Na}^{+}\right]$, is the ratio of:

$23 \mathrm{~g}\left[\mathrm{Na}^{+}\right]-58 \mathrm{~g}[\mathrm{NaCl}]$

$1.37 \mathrm{~g}\left[\mathrm{Na}^{+}\right]-\mathrm{x}$

$\mathrm{x}=3.45 \mathrm{~g} / \mathrm{dm}^{3}[\mathrm{NaCl}]$.

The remaining amount of chloride ions derived from the other compounds.

If in seawater from the Baltic in May 2009 contents sodium ion was $1.79 \mathrm{~g} / \mathrm{dm}^{3}\left[\mathrm{Na}^{+}\right]$is the ratio of:

$23 \mathrm{~g}\left[\mathrm{Na}^{+}\right]-58 \mathrm{~g}[\mathrm{NaCl}]$

$1.79 \mathrm{~g}\left[\mathrm{Na}^{+}\right]-\mathrm{x}$

$\mathrm{x}=4.51 \mathrm{~g} / \mathrm{dm}^{3}[\mathrm{NaCl}]$

The remaining amount of chloride ions derived from the other compounds.

If in seawater from the Baltic in September 2009 ion content was $1.61 \mathrm{~g} / \mathrm{dm}^{3}$ sodium $\left[\mathrm{Na}^{+}\right]$is the ratio of:

$23 \mathrm{~g}\left[\mathrm{Na}^{+}\right]-58 \mathrm{~g}[\mathrm{NaCl}]$

$1.61 \mathrm{~g}\left[\mathrm{Na}^{+}\right]-\mathrm{x}$

$\mathrm{x}=4.06 \mathrm{~g} / \mathrm{dm}^{3}[\mathrm{NaCl}]$.

The remaining amount of chloride ions derived from the other compounds.

Reduced salinity of seawater in February (2008 - 2009) may be the result of sampling together with ice particles arising in the coastal zone due to the relatively low water temperature during this period. 


\section{CONCLUSION}

It can be assumed that the average salinity of sea water in coastal waters in Międzyzdoje in 2008 - 2009 is as follows:

- In the period February 2008 the salinity of sea water $[\mathrm{NaCl}]$ was about $3.58 \mathrm{~g} / \mathrm{dm}^{3}$

- In the period May 2008 the salinity of sea water $[\mathrm{NaCl}]$ was about $4.31 \mathrm{~g} / \mathrm{dm}^{3}$

- In the period September 2008 the salinity of sea water $[\mathrm{NaCl}]$ was about $4.16 \mathrm{~g} / \mathrm{dm}^{3}$

- In the period February 2009 the salinity of sea water [NaCl] was about $3.45 \mathrm{~g} / \mathrm{dm}^{3}$

- In the period May 2009 the salinity of sea water [ $\mathrm{NaCl}]$ was about $4.51 \mathrm{~g} / \mathrm{dm}^{3}$

- In the period September 2009 the salinity of sea water $[\mathrm{NaCl}]$ was about $4.06 \mathrm{~g} / \mathrm{dm}^{3}$.

Reduced salinity of seawater in February $(2008$ - 2009) may be the result of sampling together with ice particles arising in the coastal zone due to the relatively low water temperature during this period.

\section{References}

[1] Adams W. J., Kimerle R. A., Barnett J. W. Jr., Environ. Sci. Technol. 26(10) (1992) 1864-1875.

[2] Aghor A.,. Chemicals make Thane creek the worst polluted water body, Daily DNA, August 4, 2007. Mumbai, India, 2007

[3] Alabaster J. S., Lloyds R., Water quality criteria for freshwater fish. Second edition, Butterworths publication, London 1982, pp. 361.

[4] Ali N. A., Ater M., Sunahara G. L., Robidoux P. Y., Ecotoxicology and Environmental Safety 57(3) (2004) 363-374.

[5] AMAP. Assessment report: Arctic pollution issues. Arctic Monitoring and Assessment Programme, Oslo 1998.

[6] Baršytė Lovejoy D. Acta Zoologica Lituanica. Hydrobiologia 9(2) (1999) 12-20.

[7] Baldwin D. H., Sandahl J. F., Labenia J. S., Scholz N. L. Environmental Toxicology and Chemistry 22(10) (2003) 2266-2274.

[8] Bradl H., Heavy Metals in the Environment: Origin, Interaction and Remediation, Elsevier/Academic Press, London 2005.

[9] Cai L., Liu G., Rensing C., Wang G., BMC Microbiology 9(4) (2009), doi:10.1186/1471 2180-9-4.

[10]Carlos-Tarres-Guzman M., Moreno-Sanchez R., FEMS Microbiol. Rev. 25(3) (2001) 335-347.

[11]Cervantes C., Campos-Garcia J., Debars S., Gutierrez-Corona F., Loza-Tavera H., Chatterjee J., Chatterjee C., Environ. Pollut. 109(1) (2000) 69-74.

[12] Chen M., Ma L. Q., Soil Science Society of American Journal 65(2) (2001) 491-499.

[13]Clesceri L. S., Standard methods for the examination of Water and waste water. In Arnold, E., Greenbergy, Eaton, A.D. (Eds.): Collection and Preservation of Samples And Metals, pp.1-27, pp.1-35, pp.3-1, pp.3-21, APHA, AWWA, WEF, Washington DC 1998.

[14]Dallinger R., Prosi F., Segner H., Back H., Oecologia. 73(1) (1987) 91-98. 
[15]Daniszewski P., International Letters of Chemistry, Physics and Astronomy 2 (2012) 4652.

[16]Daniszewski P., International Letters of Chemistry, Physics and Astronomy 2 (2012) 3541.

[17]Daniszewski P., International Letters of Chemistry, Physics and Astronomy 5 (2012) 7279.

[18]Daniszewski P., International Letters of Chemistry, Physics and Astronomy 5 (2012) 8087.

[19]Daniszewski P., The evolution of the geographical environment and nature protection in the industrialized and urbanized areas, (2012), 44, 16-21.

[20]Heino, R. et al. (34 authors). Past and current climate change. In: The BACC Author Team, Assessment of Climate Change for the Baltic Sea Basin. Springer Verlag, Berlin, Heidelberg. 2008,473 pp.

[21]Fagerli, H. \& S. Valiyaveetil. Atmospheric Supply of Nitrogen, Lead, Cadmium, Mercury and Dioxines/Furanes to the Baltic Sea in 2006. Available online: http:// www.helcom.fi /stc/fi les/environment/EMEP_2006/Chapter3_nitrogen.pdf [Viewed 15 January 2009] 2008.

[22]Fleming-Lehtinen V., M. Laamanen, H. Kuosa, H. Haahti, R. Olsonen, Ambio 37 (2008) $86-92$.

[23] Hongisto M., S. Joffre, Boreal Environment Research 2005, 10:1-17.

[24] Olli K., A. Clarke Å. Danielsson J. Aigars, D. J. Conley, T. Tamminen, Journal of Marine Systems 73 (2008) 284-299.

[25]Borowski T., Hryniewicz T., Rocznik Ochrony Środowiska 6 (2004) 223-232. 